\title{
Correlating Biochemical and Chemical Oxygen Demand of Effluents - A Case Study of Selected Industries in Kumasi, Ghana
}

\author{
F. K. Attiogbe ${ }^{1}$, Mary Glover-Amengor ${ }^{2}$ and K. T. Nyadziehe ${ }^{3}$ \\ ${ }^{\prime}$ Department of Chemical Engineering, Kumasi Polytechnic, Kumasi, Ghana \\ ${ }^{2}$ CSIR-Food Research Institute, P.O. Box M20, Accra, Ghana \\ ${ }^{3}$ Department of Chemical Engineering, Kwame Nkrumah University of Science and \\ Technology, Kumasi, Ghana
}

\begin{abstract}
The study aims at establishing an empirical correlation between biochemical oxygen demand $\left(\mathrm{BOD}_{5}\right)$ and chemical oxygen demand (COD) of effluents from selected industries in the Kumasi Metropolis to facilitate speedy effluent quality assessment or optimal process control. Hourly effluent samples were collected for an 8-h period three times per week for analysis of the principal parameters $\mathrm{BOD}_{5}$ and $\mathrm{COD}$, using the Standard Methods for the Examination of Water and Wastewater. Measured $\mathrm{BOD}_{5}$ and $\mathrm{COD}$ of the effluents were above the required discharged guideline of 50 $\mathrm{mg} / \mathrm{l}$ and $250 \mathrm{mg} / \mathrm{l}$, respectively, specified by the Environmental Protection Agency, Ghana. These levels of BOD 5 and COD of the wastewaters could pose potential pollution to the waterbodies in which they are discharged since untreated. Results also indicate that the degree of common variation between the two variables COD and $\mathrm{BOD}_{5}$ is highly positive for the effluents from Ghana Brewery Limited (GBL), Guinness Ghana Limited GGL) and Coca-Cola Bottling Company of Ghana (Coca-Cola), thus, the variables are correlated. However, the degree of common variation between the variables was low for the effluent from the Kumasi Abattoir. The fitted equations were GBL, $\mathrm{y}=0.6558 \mathrm{x}-270, r=$ 0.93; Coca-Cola, $\mathrm{y}=0.3536 \mathrm{x}+113.6, r=0.81$; GGL, $\mathrm{y}=0.225 \mathrm{x}+1343.7, r=0.83$; Kumasi Abattoir, $\mathrm{y}=0.1331 \mathrm{x}+$ $54806, r=0.22$ ) with $\mathrm{x}$ and $\mathrm{y}$ representing $\mathrm{COD}$ and $\mathrm{BOD}_{5}$, respectively. The $\mathrm{BOD}_{5} / \mathrm{COD}$ ratio for the wastewater from the selected industries can also be approximated to the gradient of their respective fitted equations, i.e. GBL, 0.66; Coca-Cola, 0.35; GGL, 0.23. The fitted equations for GBL, Coca-Cola and GGL can be used to facilitate rapid effluent assessment or optimal process control by these industries once the chemical oxygen demand is measured.
\end{abstract}

\section{Introduction}

Kumasi, the capital city of Ashanti Region of Ghana, is located in the south-central part of the country, about $250 \mathrm{~km}$ (by road) northwest of Accra and with an approximate size of $254 \mathrm{~km}^{2}$. Lake Bosumtwi, the largest natural lake in Ghana, is located approxi-mately $32 \mathrm{~km}$ south of Kumasi. With a population of 1,517,000 (2005, source: United Nations Population Division), Kumasi is the second-largest city in the country (http://en.wikipedia.org/wiki/kumasi). Fig. 1 shows the position of Ashanti Region and Kumasi the capital on the map of Ghana. 


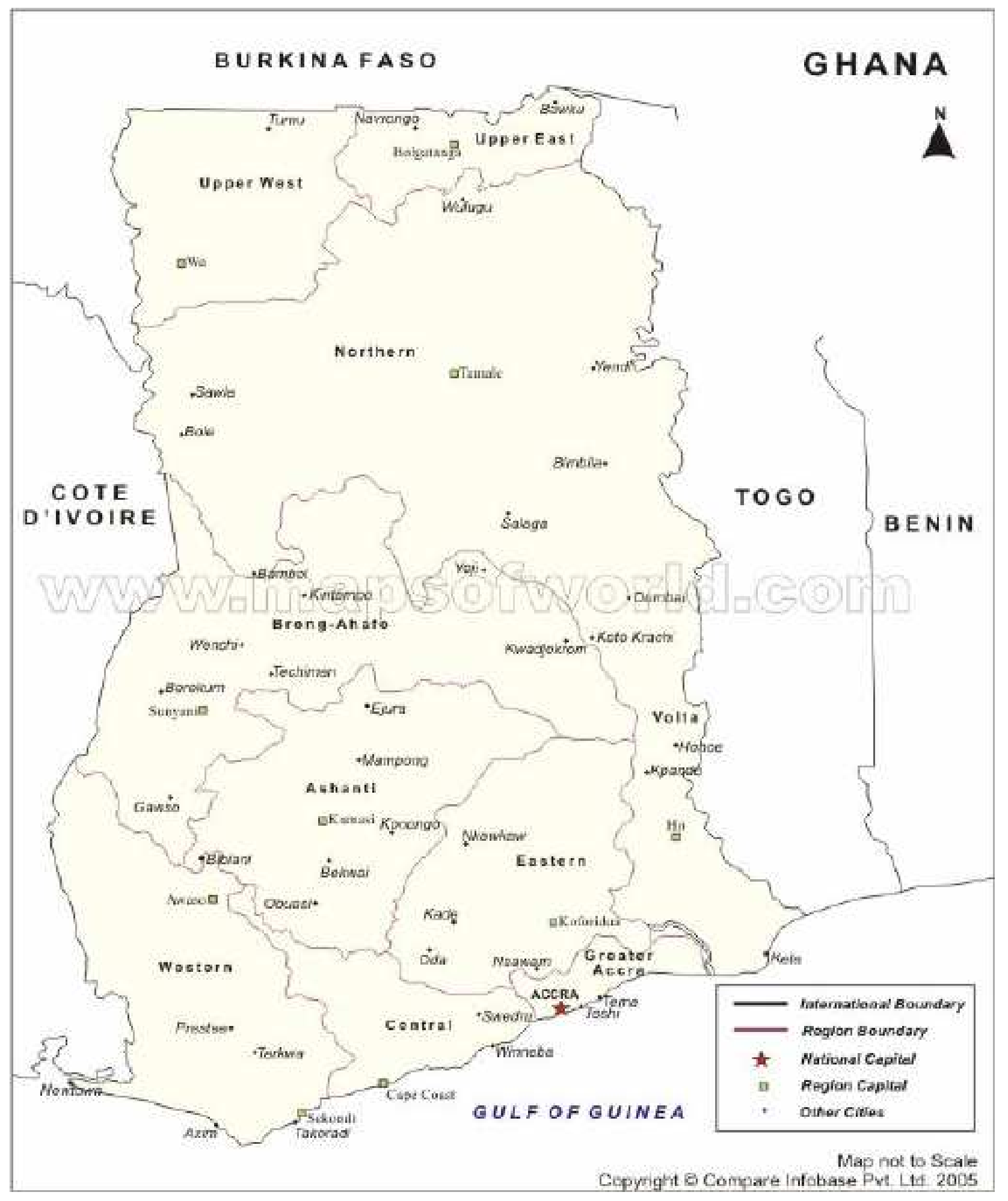

Fig. 1. Map of Ghana

The metropolis has many industries, ranging from small to large-scale enterprises. These industries are scattered in almost all the suburbs of the metropolis, with the majority concentrated at Ahensan, Kaase, Asokwa and Chirapatre areas. They are engaged in the manufacture of a 
variety of products including alcoholic beverages, soft drinks, nails, foam mattresses, lumber and plywood. There is also a slaughterhouse for animals (Sarfo-Afriyie, 1999).

Despite the economic gains derived from these industries routine visits made by the Environmental Protection Agency indicates that most of the industries use the natural resources (air, water and land) as sink for their wastes. Some of the food processing industries, including breweries, discharge untreated wastewater into the public drainage system or nearby streams. This disposal practice could constitute potential or severe pollution problems to the waterbodies since the effluents contain organic compounds that require oxygen for degradation (Sarfo-Afriyie, 1999).

If water of high organic matter content or biochemical oxygen demand (BOD) value flows into a river, the bacteria in the river will oxidize the organic matter consuming oxygen from the water faster than it dissolves back in from the air. If this happens, fish will die from lack of oxygen, a consequence known as fish kill. A stream must have a minimum of about $2 \mathrm{mg} / \mathrm{l}$ of dissolved oxygen to maintain higher life forms. In addition to this life-sustaining aspect, oxygen is important because the end products of chemical and biochemical reactions in anaerobic systems often produce aesthetically displeasing colours, tastes and odours in water (Hach et al.,1997) .

Water is a most precious resource. The cleanliness of lakes, rivers and oceans is one of the pressing goals for environmental protection. The balance of nature depends, therefore, on the comprehensiveness of the approach to solve the problem of wastewater disposal.

The most widely used parameter of organic pollution measurement applied to both wastewater and surface water is the 5-day biochemical oxygen demand $\left(\mathrm{BOD}_{5}\right)$ (Metcalf \& Eddy, 1995). The biochemical oxygen demand (BOD) is the amount of oxygen, expressed in $\mathrm{mg} / \mathrm{l}$ or part per million (p.p.m.) that bacteria take from water when they oxidized organic matter. The test is performed at a defined temperature (normally $20^{\circ} \mathrm{C}$ ) and for a standard period, which is usually 5 days (hence $\mathrm{BOD}_{5}$ ) but can be longer for specific purposes (http://www.cefic.com). During the 5day period of the BOD test, the bacteria oxidized mainly the soluble organic matter present in the water. Very little oxidation of solid (insoluble) matter occurs in that short time (Hach et_al., 1997).

Two methods are widely used for BOD measurement. One method, the dilution method, is a standard method of the American Public Health Association (APHA) and is approved by the U.S. Environmental Protection Agency (USEPA). The other method, the manometric method, has been used for over 75 years in many sewage plants and other installations throughout the world. The USEPA denied approval of this method when it selected methods for wastewater analysis, although in certain cases the USEPA has approved the manometric method (Hach et al., 1997).

The monitoring agencies, such as Environmental Protection Agency of Ghana (EPA), require that industries submit their $\mathrm{BOD}_{5}$ results periodically. However, due to the long incubation periods and low reproducibility, most industries find it very difficult to measure and report the $\mathrm{BOD}_{5}$ results of their effluents. If they measured it at all, the results provide historical data only and do not facilitate rapid water quality assessment or optimal process control. However, chemical oxygen demand (COD) measurement is simple and can reliably be carried out in the laboratory. The COD is a measure of the oxygen equivalent of the organic matter content of a sample that is susceptible to oxidation by a strong oxidant. The dichromate reflux method has been preferred over procedures using other oxidants because of superior oxidizing ability with a wide variety of samples, and ease of manipulation (Boyles, 1997).

Comparison of BOD with COD assesses whether the compound is readily biodegrad-able. For $\mathrm{BOD}_{5}$, an indication is that a COD:BOD ratio of greater than 100 means that the compound is relatively non-biodegradable and a ratio of less than 10 means it is relatively degradable. However, low $\mathrm{BOD}_{5}$ may merely mean that the test microbes need longer than the test period to 
begin breaking the compound down and, therefore, ultimate BOD or other biodegra-dation testing is generally much more reliable (http://www.cefic.com).

Analysis of the effluents $\mathrm{COD}$ and $\mathrm{BOD}_{5}$ need to be carried out and the values obtained used to establish an empirical relation for easy conversion of $\mathrm{COD}$ to $\mathrm{BOD}_{5}$. The results obtained would provide the tool for effective monitoring and evaluation of the effluent by the selected industries and the monitoring agencies. In addition, this study will facilitate rapid effluent assessment or process control by these industries once the chemical oxygen demand is measured or vice versa.

Location and duration of work

\section{Materials and methods}

The study was carried out at the Ghana Brewery Limited, the Coca-Cola Bottling Company of Ghana, Guinness Ghana Limited and the Kumasi Abattoir Company Limited because of the large volume of effluents they generate and discharge into the Sisa river. These companies are located in Ahensan and Kaase areas of the metropolis. Fig. 2 shows a map of the site (Kumasi Metropolis). 


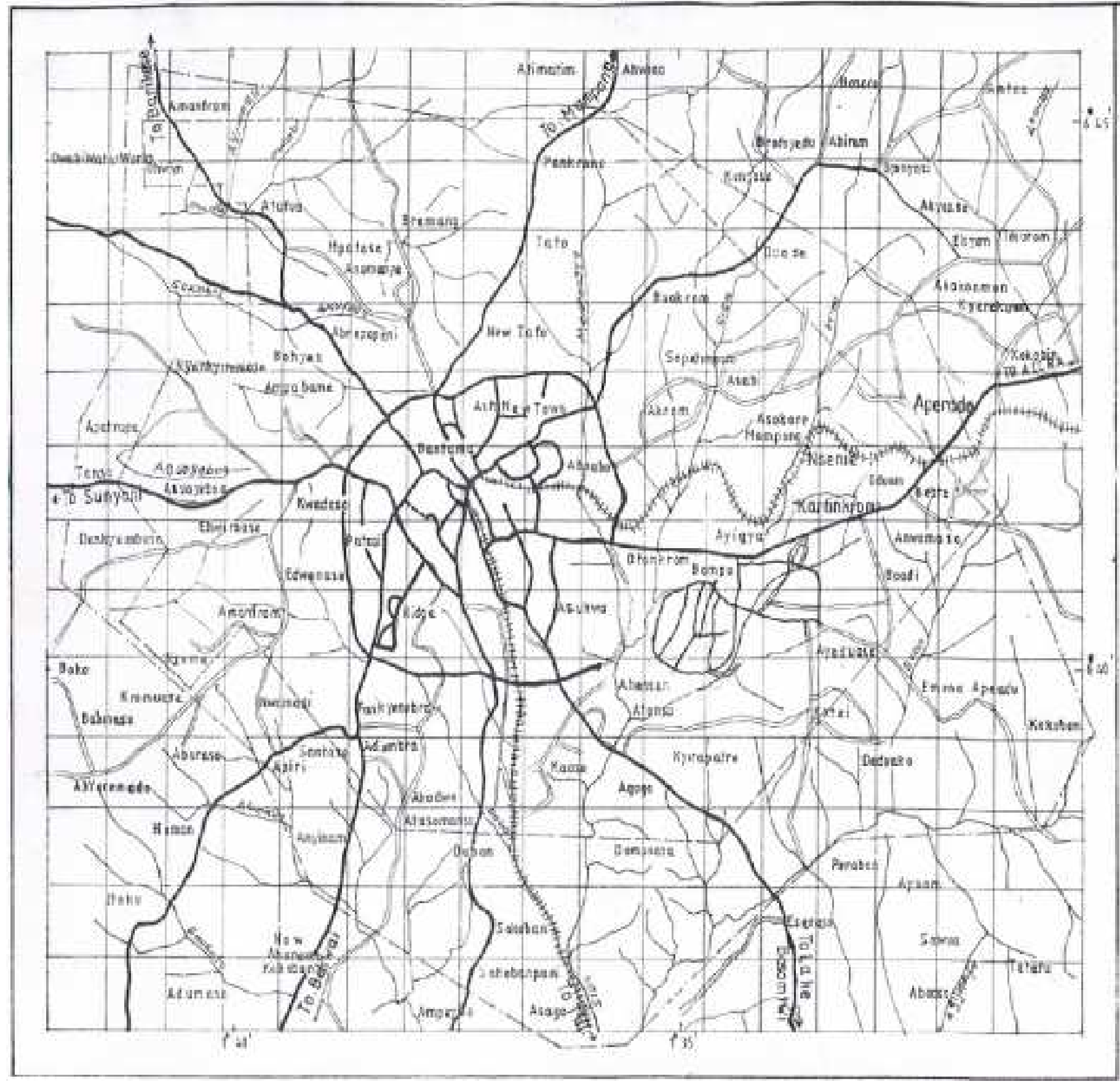

Fig. 2. Map of Kumasi (Town and Country Planning Department, Kumasi)

A period of 2 weeks was allocated to each of these industries. Sampling of wastewater was done on April 17-26, 2002 for GBL, May 2-15, 2002 for Coca-Cola, May 17-29, 2002 for GGL and May 31-June 27, 2002 for the Kumasi Abattoir. The entire period of the study was four months, spanning from April to July 2002.

\section{Sample collection}


Effluent samples were collected in well-labelled plastic bottles on hourly basis. The collection times were usually from 0800-1500 GMT. When not analyzed immediately, all samples were preserved by keeping in the refrigerator at $4{ }^{\circ} \mathrm{C}$ but analyses were carried out within $24 \mathrm{~h}$, with the exception of samples from the abattoir, which were worked on promptly. For Guinness Ghana Limited, hourly grab samples of soil were collected at the discharge point. In the case of the Kumasi Abattoir, grab samples of soil were taken from an open manhole on an hourly basis. Hourly effluent samples were collected for an 8-h period three times per week and brought to the Environmental Laboratory of the Kwame Nkrumah University of Science and Technology (KNUST) for analysis of the principal parameters, COD and $\mathrm{BOD}_{5}$, using Standard Methods for the Examination of Water and Wastewater (1992). The $p \mathrm{H}$ of the samples was also determined using a field $p \mathrm{H}$ measuring kit WTW $p \mathrm{H} 323-\mathrm{B} / \mathrm{Set}-2$.

\section{Five-day biochemical oxygen demand (dilution method)}

The dissolved oxygen content of liquid was determined by the Azide modification of the Winkler's method before and after incubation for 5 days at $20^{\circ} \mathrm{C}$. The difference gave the $\mathrm{BOD}_{5}$ of the sample after allowance had been made for the dilution, if any, of the sample. For optimum biochemical oxidation, the $p H$ s of the samples for analysis were 6.5-8 (APHA, 1992).

\section{Chemical oxygen demand (COD) using the open reflux method}

The sample, to be measured, was oxidized under reflux with a known amount of potassium dichromate in strong sulphuric acid with silver sulphate as a catalyst. Organic matter reduced part of the dichromate and the remainder was determined by titration with iron (II) ammonium sulphate or iron (II) sulphate using ferroin as indicator. Interferences from chloride were suppressed by the addition of mercuric sulphate to the reaction mixture. The chemical oxygen demand (COD) was expressed as milligrams of oxygen absorbed from standard dichromate per litre of sample (APHA, 1992).

\section{Results}

The daily $\mathrm{BOD}_{5}$ variation of the effluent from GBL ranged from $323 \mathrm{mg} / \mathrm{l}$ to $33,426 \mathrm{mg} / \mathrm{l}$. Most of the higher values for $\mathrm{BOD}_{5}$ were obtained during the cleaning of the process vessels. The corresponding COD ranged from $430 \mathrm{mg} / \mathrm{l}$ to $44,800 \mathrm{mg} / \mathrm{l}$. The same applied to effluent from GGL where higher $\mathrm{BOD}_{5}$ values were registered when spent yeast was discharged together with the other processing wastewaters. The $\mathrm{BOD}_{5}$ ranges from $1,000 \mathrm{mg} / \mathrm{l}$ to $40,000 \mathrm{mg} / \mathrm{l}$ and the corresponding COD from $1,356 \mathrm{mg} / \mathrm{l}$ to $112,000 \mathrm{mg} / \mathrm{l}$. Values ranging from $10,000 \mathrm{mg} / \mathrm{l}$ to $230,000 \mathrm{mg} / \mathrm{l}$ for $\mathrm{BOD}_{5}$ and $8000 \mathrm{mg} / \mathrm{l}$ to $472,000 \mathrm{mg} / \mathrm{l}$ for COD were obtained for wastewater from the Kumasi Abattoir. The effluent from the Coca-Cola Bottling Company, however, recorded the lowest daily $\mathrm{BOD}_{5}$ and COD values ranging from $75 \mathrm{mg} / \mathrm{l}$ to $1,744 \mathrm{mg} / \mathrm{l}$ and 142 $\mathrm{mg} / \mathrm{l}$ to $3,560 \mathrm{mg} / \mathrm{l}$, respectively. The average daily hourly $\mathrm{BOD}_{5}, \mathrm{COD}$ and $\mathrm{COD} / \mathrm{BOD}_{5}$ ratio values for the selected industries are shown in Tables 1-4.

TABLE 1

Average daily hourly $\mathrm{BOD}_{5}$ and $C O D$ values for $G B L$

$\begin{array}{rrrrrrrr}\text { Parameter } & \text { Unit } & 1 & 2 & 3 & 4 & 5 & 6 \\ & & & & & & & \\ \mathrm{BOD}_{5} & \mathrm{mg} / \mathrm{l} & 2,918 & 3719 & 5,259 & 4,281 & 2,624 & 4,941\end{array}$




$\begin{array}{lrrrrrrr}\mathrm{COD} & \mathrm{mg} / 1 & 3,988 & 5519 & 7,478 & 7,338 & 6,405 & 6,667 \\ \mathrm{COD} / \mathrm{BOD}_{5} & & 1.37 & 1.48 & 1.42 & 1.71 & 2.44 & 1.35\end{array}$

TABLE 2

Average daily hourly $\mathrm{BOD}_{5}$ and $C O D$ values for Coca-Cola

$\begin{array}{lrrrrrrr}\text { Parameter } & \text { Unit } & 1 & 2 & 3 & 4 & 5 & 6 \\ & & & & & & & \\ \mathrm{BOD}_{5} & \mathrm{mg} / \mathrm{l} & 336 & 678 & 317 & 202 & 603 & 345 \\ \mathrm{COD} & \mathrm{mg} / \mathrm{l} & 627 & 1,457 & 535 & 421 & 1,172 & 878 \\ \mathrm{COD} / \mathrm{BOD}_{5} & & 1.87 & 2.18 & 1.69 & 2.02 & 1.94 & 2.54\end{array}$

TABLE 3

Average daily hourly $\mathrm{BOD}_{5}$ and $C O D$ values for $G G L$

$\begin{array}{lrrrrrrr}\text { Parameter } & \text { Unit } & & & & & & \\ & & 1 & 2 & 3 & 4 & 5 & 6 \\ \mathrm{BOD}_{5} & \mathrm{mg} / 1 & 2,844 & 3,946 & 4,938 & 4,425 & 3,775 & 9,213 \\ \mathrm{COD} & \mathrm{mg} / 1 & 10,061 & 19,131 & 11,973 & 12,122 & 8,263 & 32,132 \\ \mathrm{COD} / \mathrm{BOD}_{5} & & 3.54 & 4.85 & 2.42 & 2.74 & 2.19 & 3.49\end{array}$

TABLE 4

Average daily hourly $\mathrm{BOD}_{5}$ and $\mathrm{COD}$ values for Kumasi Abattoir

\begin{tabular}{|c|c|c|c|c|c|c|c|c|c|}
\hline \multirow[t]{2}{*}{ Parameter } & \multicolumn{9}{|l|}{ Unit } \\
\hline & 1 & 2 & 3 & 4 & 5 & 6 & 7 & & \\
\hline $\mathrm{BOD}_{5}$ & $\mathrm{mg} / \mathrm{l}$ & 87,756 & 71,875 & 37,800 & 48,921 & 128,813 & 52,875 & 70,750 & 33,875 \\
\hline COD & $\mathrm{mg} / \mathrm{l}$ & 30,375 & 56,625 & 136,540 & 34,613 & 247,225 & 79,073 & 39,250 & 46,375 \\
\hline $\mathrm{COD} / \mathrm{BOD}_{5}$ & & 0.35 & 0.79 & 3.61 & 0.71 & 1.92 & 1.50 & 0.55 & 1.37 \\
\hline
\end{tabular}

The linear regression results obtained during the effluent analysis from the selected industries in the Kumasi Metropolis are shown in Fig. 3-6. A linear response was obtained between the data sets. The fitted equations on the entire data $\left(\mathrm{COD}\right.$ and $\left.\mathrm{BOD}_{5}\right)$ set on a particular industry are generated with their corresponding correlation coefficients $(r)$. 


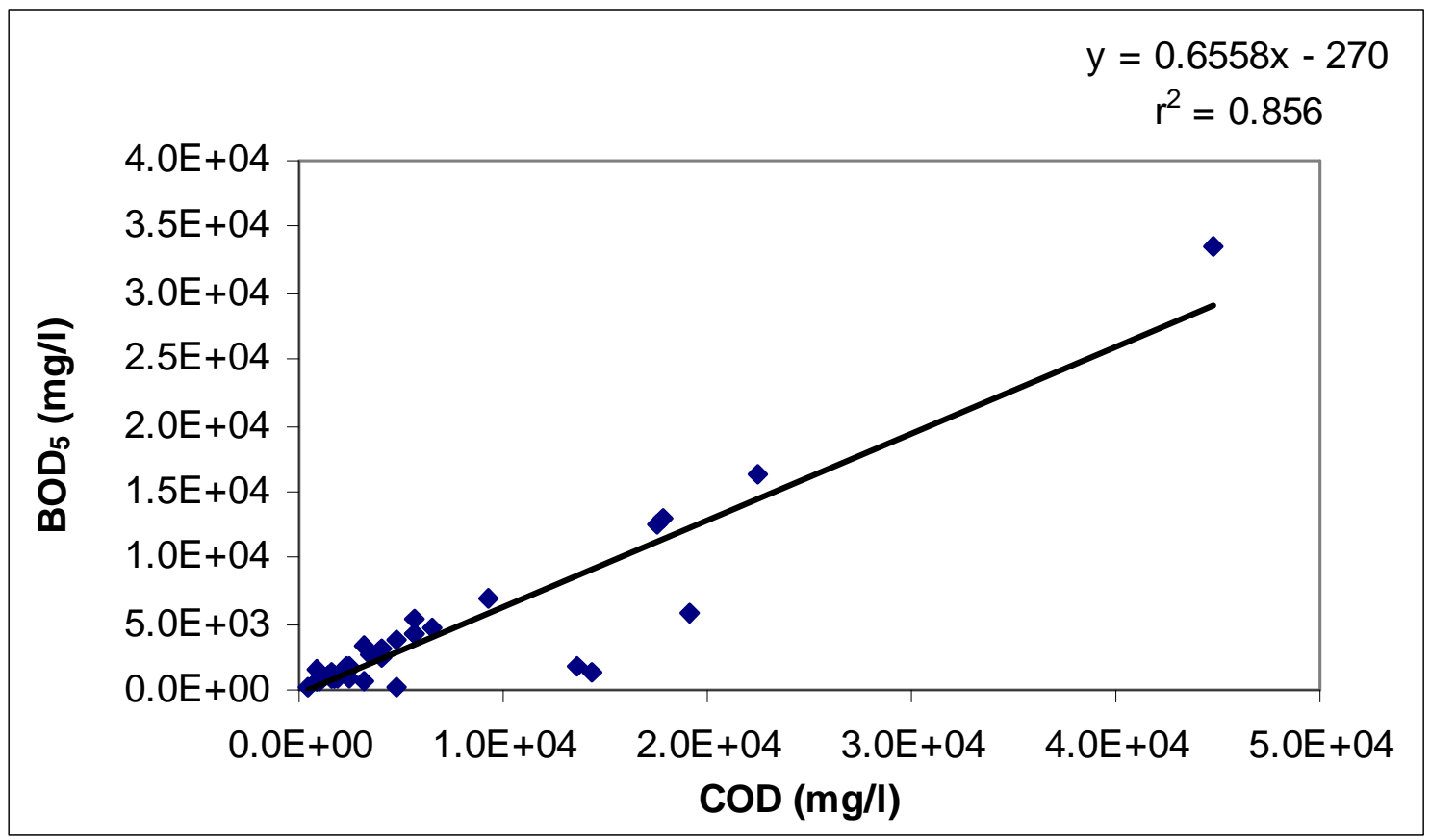

Fig. 3. Linear regression of $\mathrm{BOD}_{5}$ and COD of wastewater from GBL

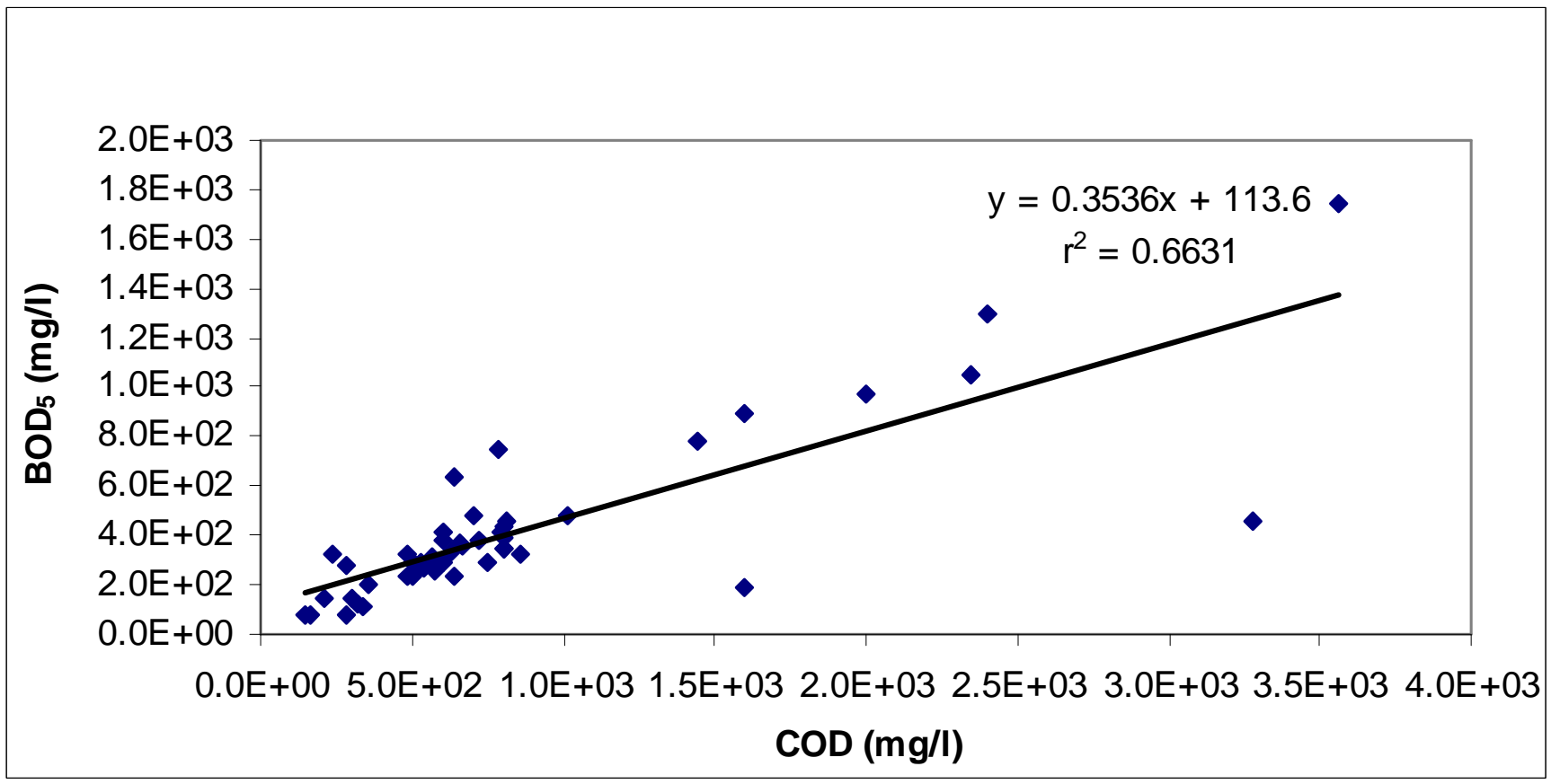

Fig. 4. Linear regression of $\mathrm{BOD}_{5}$ and $\mathrm{COD}$ of wastewater from the Coca-Cola 


$$
\begin{gathered}
y=0.225 x+1343.7 \\
r^{2}=0.6856
\end{gathered}
$$

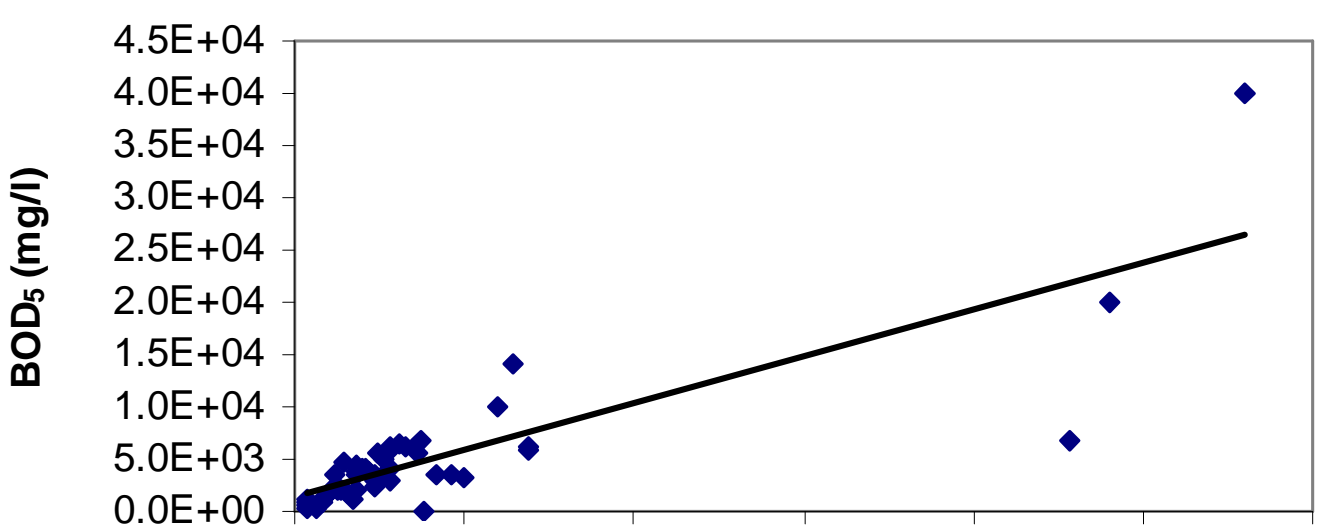

$0.0 \mathrm{E}+00 \quad 2.0 \mathrm{E}+04 \quad 4.0 \mathrm{E}+04 \quad 6.0 \mathrm{E}+04 \quad 8.0 \mathrm{E}+04 \quad 1.0 \mathrm{E}+05 \quad 1.2 \mathrm{E}+05$ $\operatorname{COD}(\mathrm{mg} / \mathrm{l})$

Fig. 5. Linear regression of $\mathrm{BOD}_{5}$ and $\mathrm{COD}$ of wastewater from GGL

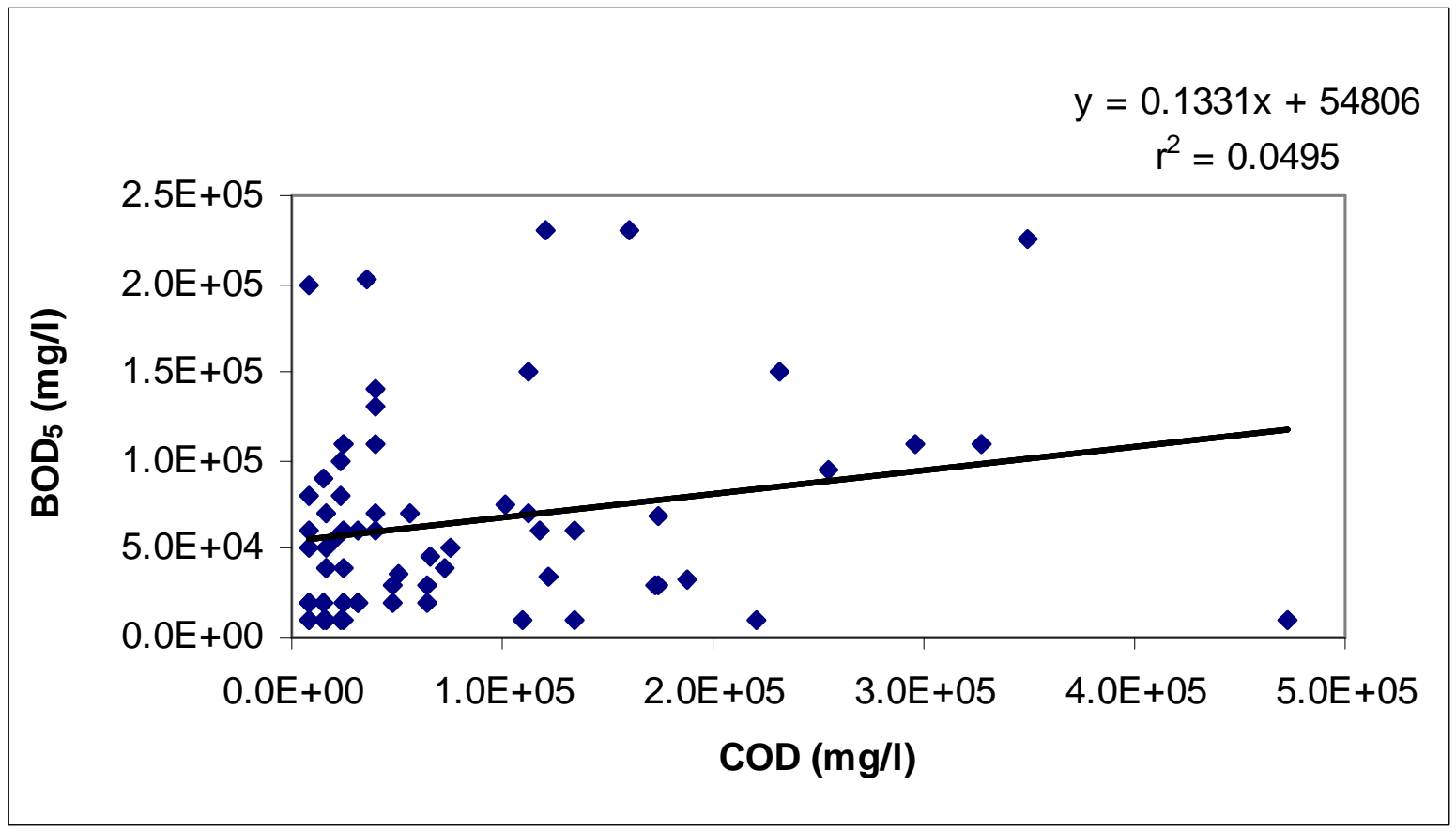

Fig. 6. Linear regression of $\mathrm{BOD}_{5}$ and $\mathrm{COD}$ of wastewater from Kumasi Abattoir Company Limited

The correlation coefficients of the fitted equations were generally positive for the results from the Ghana Brewery Limited samples analysis, being between 0.14 and 1.00. For Guinness Ghana Limited, the correlation coefficients were between 0.21 and 0.95 . However, the correlation coefficient of the entire data on GGL gave $r=0.83$.

In the case of Coca-Cola, the correlation coefficients of the fitted equations were positive being between 0.40 and 1.00. The fitted equations correlation coefficients for the results from the daily 
analysis of the abattoir effluent were generally near zero being between 0.22 and 0.85 . The exceptional correlation coefficient of 0.85 was obtained for a particular day analysis.

The following can be deduced:

1. The COD and the $\mathrm{BOD}_{5}$ results obtained for GBL, Coca-Cola and the GGL showed that the degree of common variation between the two variables was highly positive; thus, the COD and the $\mathrm{BOD}_{5}$ are said to be highly correlated.

2. The fitted equations were $y=0.6558 x-270(G B L), y=0.3536 x+113.6$ (Coca-Cola) and $y=$ $0.225 \mathrm{x}+1343.7$ (GGL).

3. The correlation coefficients of the equations for the GBL, Coca-Cola and GGL were highly positive being $0.93,0.81$ and 0.83 , respectively.

The $\mathrm{BOD}_{5} / \mathrm{COD}$ ratio for GBL, Coca-Cola and GGL can be approximated to the gradient of their respective fitted equations, i.e. $0.66,0.35$ and 0.23 .

However, the result obtained for the Kumasi Abattoir Company Limited showed the degree of common variation between the $\mathrm{COD}$ and the $\mathrm{BOD}_{5}$ to be very low. The fitted equation was $\mathrm{y}=$ $0.1331 \mathrm{x}+54806$ and the correlation coefficient being 0.22 . For correlation coefficient $r$ near zero, it means that there is no linear correlation between the variables. In other words, the correlation coefficient measures the goodness of fit of the equation actually assumed to the data (Ayyub \& McCuen, 1997). Thus, there is almost no linear correlation between the COD and the $\mathrm{BOD}_{5}$ for this effluent and, thus, a linear equation cannot be assumed.

\section{Discussion}

The $\mathrm{BOD}_{5}$ and the $\mathrm{COD}$ values obtained on analysis of the effluents of the selected industries have been found to be higher than expected from Environmental Protection Agency, Ghana Standards guideline for discharge $\left(\mathrm{BOD}_{5}, 50 \mathrm{mg} / \mathrm{l}\right.$ and the COD, $\left.250 \mathrm{mg} / \mathrm{l}\right)$. These levels of $\mathrm{BOD}_{5}$ and COD could constitute potential pollution problems to the waterbodies since they contain organic compounds that will require a large quantity of oxygen for degradation. The COD of some of the samples were lower than the $\mathrm{BOD}_{5}$ for the abattoir wastewater and this could be attributed to the presence of ammonia which is noted to significantly increase measured BOD as a result of microbial oxidation of the ammonia (ultimately to $\mathrm{NO}_{3}$ ) (http://www.cefic.com).

The COD:BOD 5 ratios for all the selected industries have been found to be less than 10 . This implies that the compounds in the effluents of these industries were relatively degradable, thus, a possible depletion of the dissolved oxygen in the receiving river and a potential effect on aquatic life. The COD correlates positively with the $\mathrm{BOD}_{5}$ of the wastewaters from GBL, GGL and CocaCola. The correlation equations can be used to estimate the $\mathrm{BOD}_{5}$ for reporting and for process control.

The negative correlation of the chemical oxygen demand (COD) to the 5-day biochemical oxygen demand $\left(\mathrm{BOD}_{5}\right)$ at the instances that these occur could be attributed to the composition or characteristics of the waste (effluent) not being constant (http://www.hach.com), and this is supported by the wide variation in correlation value from the linear regression of the Kumasi Abattoir wastewater (Fig. 6).

\section{Conclusion}

The degree of common variation between the $\mathrm{COD}$ and the $\mathrm{BOD}_{5}$ of the wastewaters from the GBL, Coca-Cola and GGL was highly positive, thus, the two parameters are correlated with good correlation coefficients of $0.93,0.81$ and 0.83 , respectively. The correlation coefficient of the fitted equation for prediction for Ghana Brewery Limited, Guinness Ghana Limited and The Coca-Cola Bottling Company of Ghana may, therefore, be used to facilitate rapid effluent quality 
assessment or optimal process control by these industries once the chemical oxygen demand (COD) is measured or vice versa.

\section{Acknowledgement}

The authors would like to thank the following industries for allowing them to work on their effluents: Ghana Brewery Limited, The Coca-Cola Bottling Company of Ghana, Guinness Ghana Limited and the Kumasi Abattoir Company Limited. Special thanks go to Prof. (Mrs) Esi Awuah of the Civil Engineering Department of Kwame Nkrumah University of Science and Technology, Kumasi, Ghana and Mr Christian Dela Dedzo of Soil Research Institute, Kumasi, Ghana, for their immense assistance.

\section{References}

APHA (1992). Standard Methods for Water and Wastewater Examination, 18th edn. American Public Health Association, Washington, D.C.

Ayyub B. M. and McCuen R. H. (1997). Probability, Statistics and Reliability for Engineers. CRC Press LLC, New York, U.S.A.

Boyles W. (1997a). The Science of Chemical Oxygen Demand. Technical Information Series, Booklet No. 9. Hach Company, U.S.A.

Boyles W. (1997b). Manganese III Chemical Oxygen Demand. Technical Paper. Hach Company, U.S.A.

Hach C. C., Klein R. L. Jr. and Gibbs C. R., (1997). Introduction to Biochemical Oxygen Demand; Technical Information Series. Booklet No. 7. Hach Company, U.S.A.

Metcalf and Eddy Inc. (1995). Wastewater Engineering: Treatment, disposal and reuse, 3rd edn. (G. Tchobanoglous and F. L. Burton, ed.) Tata McGraw-Hill Publishing Company Ltd, New Delhi.

Sarfo-Afriyie Y. (1999). A Study of Industrial Waste Management in Kumasi (Case Study). Kumasi Brewery Limited, The Coca-Cola Bottling Company of Ghana. 